\title{
Correlation between red cell distribution width, systolic function and atrial fibrillation occurrence in patients with acute ST segment elevation myocardial infarction
}

\author{
Jasmina Ćatić*, \\ Ovana Jurin, \\ Marko Lucijanić, \\ Sandra Jakšić \\ Jurinjak, \\ Tomislava Bodrožić \\ Džakić Poljak, \\ Robert Blažeković
}

University Hospital Dubrava, Zagreb, Croatia

RECEIVED:

September 9, 2017

ACCEPTED:

September 26, 2017

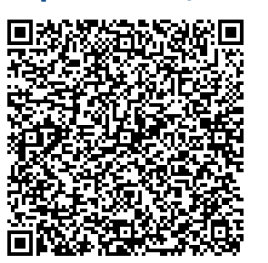

KEYWORDS: Red cell distribution width, systolic function, ST segment elevation myocardial infarction. CITATION: Cardiol Croat. 2017;12(9-10):346. | https://doi.org/10.15836/ccar2017.346

*ADDRESS FOR CORRESPONDENCE: Jasmina Ćatić, Klinička bolnica Dubrava, Avenija Gojka Šuška 6, HR-10000 Zagreb, Croatia. / Phone: +38591-2577-725 / E-mail: jcjasmina@gmail.com

ORCID: Jasmina Ćatić http://orcid.org/0000-0001-6582-4201 • Ivana Jurin http://orcid.org/0000-0002-2637-9691 Marko Lucijanić http://orcid.org/0000-0002-1372-2040 • Sandra Jakšić Jurinjak http://orcid.org/0000-0002-7349-6137 Tomislava Bodrožić Džakić Poljak http://orcid.org/0000-0002-7293-3972

Robert Blažeković http://orcid.org/0000-0001-7125-361X

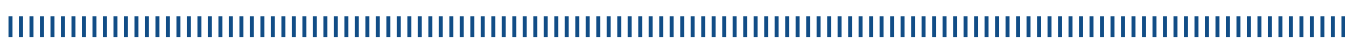

Aim: Red cell distribution width as an indicator of inflammation has been shown as a predictive and prognostic factor in coronary artery disease as well as in heart failure ${ }^{1,2}$. The aim of this study was to evaluate correlation between red cell distribution width (RDW) and echocardiographic parameters of systolic FUNCTION and atrial fibrillation occurrence in patients with acute ST segment elevation myocardial infarction (STEMI).

Patients and Methods: We recruited 89 patients with acute myocardial infarction with ST elevation who were hospitalized in the Department of Cardiovascular Diseases, University Hospital Dubrava, Zagreb. Complete blood count was determined from blood samples prior to percutaneous coronary intervention (PCI). Echocardiographic exam was performed by two independent experts after PCI.

Results: RDW was negatively correlated with ejection fraction ( $p=0.026, R h o=-0.24$ ), patients with EF $<50 \%$ had higher RDW values (14.35 vs $13.8 \%$, $\mathrm{p}=0.009)$ as well as patients with $\mathrm{EF}<40 \%$ (15.8\% vs $13.9 \%$, $\mathrm{p}=0.008$ ). As expected, TIMI score was correlated with systolic function and RDW values. Patients with higher values of RDW had higher risk of developing atrial fibrillation in the follow- up period $(>14.5 \%$, $\mathrm{P}=0.00, \mathrm{HR}=3.99$ ).

Conclusion: Increased RDW values on admission in STEMI patients treated with PCI are associated with systolic dysfunction and atrial fibrillation occurrence in the follow -up period. These findings can guide further clinical practice but must be confirmed in future studies with more patients.

1. Zalawadiya SK, Veeranna V, Niraj A, Pradhan J, Afonso L. Red cell distribution width and risk of coronary heart disease events. Am J Cardiol. 2010 0ct 1;106(7):988-93. https://doi.org/10.1016/j.amjcard.2010.06.006

2. Uyarel H, Ergelen $M$, Cicek G, Kaya MG, Ayhan E, Turkkan C, et al. Red cell distribution width as a novel prognostic marker in patients undergoing primary angioplasty for acute myocardial infarction. Coron Artery Dis. 2011 May:22(3):138-44.

https://doi.org/10.1097/MCA.0b013e328342c77b 